\title{
Development and Validation of a Stability Indicating RP-UPLC Method for Analysis of Imipramine Hydrochloride in Pharmaceuticals
}

\author{
H. N. Deepakumari, K. B. Vinay, and H. D. Revanasiddappa \\ Department of Chemistry, University of Mysore, Manasagangothri, Mysore 570 006, India \\ Correspondence should be addressed to H. D. Revanasiddappa; hdrevanasiddappa@yahoo.com
}

Received 27 May 2013; Accepted 15 July 2013

Academic Editors: R. N. Rao and A. Tsantili-Kakoulidou

Copyright (C) 2013 H. N. Deepakumari et al. This is an open access article distributed under the Creative Commons Attribution License, which permits unrestricted use, distribution, and reproduction in any medium, provided the original work is properly cited.

\begin{abstract}
The objective of the current study was the development of a simple, rapid, and accurate isocratic reverse-phase ultra-performance liquid chromatographic (RP-UPLC) method for the routine control analysis of imipramine hydrochloride (IMH) in bulk drug and in pharmaceutical formulations. This work was carried out in order to reduce analysis time and maintaining good efficiency which in turn is focused on high-speed chromatographic separations. The method was developed using Waters Acquity BEH C18 column $(100 \mathrm{~mm} \times 2.1 \mathrm{~mm}, 1.7 \mu \mathrm{m})$ with mobile phase consisting of a mixture of acetonitrile and ammonium acetate buffer of $\mathrm{pH}-5$ ( $80: 20$, $\mathrm{v} / \mathrm{v} / \mathrm{v})$. UV detection was performed at $220 \mathrm{~nm}$ for eluted compound. An excellent linearity was observed in the concentration range $0.2-3 \mu \mathrm{g} / \mathrm{mL}$ IMH with a regression coefficient $\left(r^{2}\right)$ value of 0.9999 . The method developed was validated and forced degradation was performed as per ICH guidelines. The limit of detection $(S / N=3)$ was $0.2532 \mathrm{ng} / \mathrm{mL}$ and the limit of quantitation $(S / N=10)$ was found to be $0.7672 \mathrm{ng} / \mathrm{mL}$. The drug IMH was subjected to hydrolytic, acidic, basic, thermal, photolytic, and oxidative stress conditions according to ICH regulations. IMH was found to be stable in basic, thermal, and photolytic conditions and degrades in acidic, hydrolytic, and oxidative stress conditions.
\end{abstract}

\section{Introduction}

Imipramine hydrochloride (IMH) is a tricyclic antidepressant. It is a dibenzazepine derivative and chemically IMH is 3-(10,11-Dihydro-5H-dibenz[b,f]azepin-5-yl) propyldimethylamine hydrochloride (Figure 1). IMH is commonly used to treat the depressive disorders owing to their efficiency in elevating the mood of patients by interfering to the reuptake of norepinephrine or serotonin [1]. The drug is official in European Pharmacopoeia [2].

The literature on the methods for the determination of IMH is vast. Several analytical methods have been reported for the determination of IMH in biological fluids and/or pharmaceutical formulations. These include chromatographic techniques like HPLC [3-9], TLC [10], GC [1114], LC with direct injection and electrochemical detection [15], adsorptive stripping voltammetry [16], chemometric methods [17], flow-injection extraction spectrophotometry
[18], derivative spectrophotometry [19, 20], and visible spectrophotometry [20-24].

Many of the reported methods for the determination of imipramine suffer from one or the other disadvantages like time consuming and require expensive experimental setup [11-14], and chemometric methods are less sensitive [17]. Besides, the reported spectrophotometric methods are less sensitive [18-24] and require extraction procedures [23] and costly chromogenic reagent [24] (Table 1). Considering these demerits, there was a need to develop a more advantageous chromatographic method for the determination of IMH in bulk sample and in tablets.

To our present knowledge, no validated stability indicating UPLC assay method for the determination of IMH in pharmaceutical formulation was available in the literature. Though the numbers of liquid [3-9], thin layer [10], gas chromatographic methods [11-14], and LC with direct injection and electrochemical detection [15] have been reported 


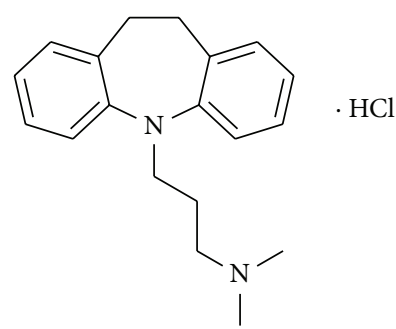

FIGURE 1: Structure of imipramine hydrochloride.

earlier for IMH, no attempt has been made to apply this new type of ultra performance liquid chromatography for its determination in pharmaceuticals.

The present work deals with a stability-indicating RP-UPLC method for the quantitative determination of imipramine $\mathrm{HCl}$ in bulk and in tablets. This method was successfully validated according to the International Conference Harmonization (ICH) guidelines [25].

\section{Experimental}

2.1. Chemicals and Reagents. Pharmaceutical grade $\mathrm{IMH}$ (purity $\geq 98.9 \%$ ) was supplied by Cipla India Ltd., Mumbai, India, as a gift sample and was used as received. Pharmaceutical formulations of IMH such as imipramine (Sun) and Depranil (La Pharma) samples were purchased from local markets. HPLC grade acetonitrile was purchased from $\mathrm{RCl}$ Labscan, Hyderabad, India. Water HPLC grade was obtained from a Milli-Q water purification system, Bedford, USA. Analytical grade ammonium acetate and $80 \%$ phosphoric acid were obtained from Ranbaxy Fine Chemicals, New Delhi, India.

2.2. Buffer Preparation. Solution of ammonium acetate $(0.08 \mathrm{M})$ was prepared by dissolving $0.6167 \mathrm{~g}$ of ammonium acetate in one litre of water. The $\mathrm{pH}$ of this solution was adjusted to 5.0 with phosphoric acid. The buffer solution was found stable with respect to $\mathrm{pH}$ and visual clarity for $48 \mathrm{~h}$.

2.3. Ultra-Performance Liquid Chromatographic Conditions. UPLC analysis was carried out on a Waters Acquity UPLC system (Waters, Manchester, UK). The output signal was monitored and processed using Empower-2 software. The chromatographic column used was Acquity BEH column (C$18100 \mathrm{~mm}, 2.1 \mathrm{~mm}$, and $1.7 \mu \mathrm{m}$; Waters, Manchester, UK) equipped with binary solvent delivery pump, autosampler, and tunable UV (TUV) detector. The solvent contains a mixture of $0.08 \mathrm{M}$ ammonium acetate buffer and acetonitrile in the ratio $20: 80(\mathrm{v} / \mathrm{v} / \mathrm{v})$. Total cycle time was $6 \mathrm{~min}$ with a flow rate of $0.3 \mathrm{~mL} / \mathrm{min}$ and an injection volume of $2 \mu \mathrm{L}$ using partial loop mode. The isocratic flow rate of mobile phase was maintained at $0.3 \mathrm{~mL} / \mathrm{min}$. The column temperature was adjusted to $25^{\circ} \mathrm{C}$. The sample run was monitored at $220 \mathrm{~nm}$ and the run time was $6.0 \mathrm{~min}$. The retention time of the sample was observed at about $2.0 \mathrm{~min}$.
2.4. Preparation of Stock Solution. A stock standard solution equivalent to $100 \mu \mathrm{g} / \mathrm{mL}$ of IMH was prepared by dissolving accurately weighed $10 \mathrm{mg}$ of pure IMH in a $100 \mathrm{~mL}$ volumetric flask and diluted to mark with the mobile phase and filtered through a $0.22 \mu \mathrm{m}$ nylon membrane filter. Working solutions were prepared as required by dilution with the same solvent and the solution obtained was analyzed by UPLC.

2.5. Preparation of Sample Solution. For the preparation of IMH solution, IMH tablet samples such as imipramine and Depranil were purchased from local markets. $10 \mathrm{mg}$ of finely pulverized tablets was accurately weighed and transferred to a $100 \mathrm{~mL}$ volumetric flask. To this $20 \mathrm{~mL}$ of mobile phase acetonitrile, ammonium acetate buffer, $(80: 20, \mathrm{v} / \mathrm{v})$ was added and the mixture was sonicated, and the volume was diluted to the mark with mobile phase to yield a concentration of $100 \mu \mathrm{g} / \mathrm{mL}$. Working solutions were prepared as required by dilution with the same solvent and the samples were filtered through a $0.22 \mu \mathrm{m}$ nylon membrane filter prior to the injection into UPLC system.

2.6. Stress Studies. Forced degradation studies were carried out for imipramine to provide an indication of the stability indicating property and specificity of the proposed method. Forced degradation of drug substances was carried out under acidic, basic, neutral, oxidative, photolytic, and thermal stress conditions.

2.6.1. Acid Hydrolysis. For acid decomposition studies, IMH bulk sample was dissolved in $0.1 \mathrm{M} \mathrm{HCl}$ at a concentration of $1 \mu \mathrm{g} / \mathrm{mL}$ and the solution was heated at $80^{\circ} \mathrm{C}$ for a period of $6 \mathrm{~h}$. Before carrying out the UPLC analysis, samples were suitably diluted and neutralized with $0.1 \mathrm{~N} \mathrm{NaOH}$.

2.6.2. Base Hydrolysis. The studies in alkaline conditions were done in $0.1 \mathrm{M} \mathrm{NaOH}$ at a concentration of $1 \mu \mathrm{g} / \mathrm{mL}$ and the solution was heated at $80^{\circ} \mathrm{C}$ for a period of $6 \mathrm{~h}$. Before carrying out the UPLC analysis, samples were suitably diluted and neutralized with $0.1 \mathrm{~N} \mathrm{HCl}$.

2.6.3. Oxidation. Hydrogen peroxide was utilized for the oxidative degradation study. The drug substance was treated with $5 \%$ hydrogen peroxide solution at $80^{\circ} \mathrm{C}$ for a period of $6 \mathrm{~h}$.

2.6.4. Thermal Degradation Studies. To investigate the susceptibility of the drug under thermal stress conditions, the drug was spread in a borosilicate glass petri dish and placed in the hot-air oven maintained at $80^{\circ} \mathrm{C}$ for $24 \mathrm{~h}$.

2.6.5. Photolytic Degradation Studies. Photodegradation studies were carried out by exposing the drug in solution $(1 \mu \mathrm{g} / \mathrm{mL})$ and solid state (powder) drug in a photostability chamber for 10 days. The samples of both solution and powder were kept in parallel in darkness (wrapped) for the same period. Samples were withdrawn after $24 \mathrm{~h}$ and analyzed. 
TABLE 1: Comparison of the performance characteristics of the proposed method with some of the existing chromatographic/spectrophotometric methods.

\begin{tabular}{|c|c|c|c|c|c|}
\hline Sl No. & Reagent/s used & Methodology & Linear range & Remarks & References \\
\hline 1 & $\mathrm{NaClO}_{4}$-buffer ethanol & Derivative spectrophotometry & $0.62-10.14 \mu \mathrm{g} / \mathrm{mL}$ & $\begin{array}{c}\text { Sensitive but lack of } \\
\text { selectivity }\end{array}$ & [19] \\
\hline 2 & Methyl orange & $\begin{array}{l}\text { Formation of ion pair with } \\
\text { methyl orange and the } \\
\text { absorbance was measured at } \\
425 \mathrm{~nm}\end{array}$ & $0.79-25.3 \mu \mathrm{g} / \mathrm{mL}$ & Less sensitive & {$[21]$} \\
\hline 3 & Eriochrome cyanine R & $\begin{array}{l}\text { Reacts in neutral medium with } \\
\text { imipramine forming reddish } \\
\text { compound }\end{array}$ & $10-80 \mu \mathrm{g} / \mathrm{mL}$ & $\begin{array}{l}\text { Less sensitive and has } \\
\text { narrow range }\end{array}$ & {$[22]$} \\
\hline 4 & $\begin{array}{l}\text { Iminodibenzyl } \\
\text { p-chloranilic acid }\end{array}$ & $\begin{array}{l}\text { First derivative of ratio spectra } \\
\text { Formation of purple colored } \\
\text { charge transfer complex }\end{array}$ & $\begin{array}{c}5-30 \mu \mathrm{g} / \mathrm{mL} \\
20-200 \mu \mathrm{g} / \mathrm{mL}\end{array}$ & $\begin{array}{l}\text { Less sensitive and } \\
\text { very narrow range }\end{array}$ & {$[20]$} \\
\hline 5 & $\begin{array}{l}\text { Azocarmine G } \\
\text { Naphthalene blue } \\
\text { Woolfast blue BL }\end{array}$ & $\begin{array}{l}\text { Extracts of the ion associates } \\
\text { exhibit absorption maxima } \\
\text { at } 550(\mathrm{ACG}) \\
620(\mathrm{NB}) \text {, and } \\
590(\mathrm{WFB} \mathrm{BL}) \mathrm{nm}\end{array}$ & $\begin{array}{l}2.0-12.0 \mu \mathrm{g} / \mathrm{mL} \\
4.0-16.0 \mu \mathrm{g} / \mathrm{mL} \\
1.0-12.0 \mu \mathrm{g} / \mathrm{mL}\end{array}$ & $\begin{array}{l}\text { Sensitive but requires } \\
\text { tedious extraction } \\
\text { procedures }\end{array}$ & {$[23]$} \\
\hline 6 & $\begin{array}{l}\text { 3-Methylbenzothiazolin-2-one } \\
\text { hydrazone-iron(III)chloride }\end{array}$ & $\begin{array}{l}\text { Oxidative coupling of the drugs } \\
\text { with } \\
\text { 3-methylbenzothiazolin-2-one } \\
\text { hydrazone which shows } \\
\text { maximum absorption at } 630 \mathrm{~nm}\end{array}$ & $\begin{array}{l}1.0-25 \mu \mathrm{g} / \mathrm{mL} \\
\left(€=3.20 \times 10^{3}\right)\end{array}$ & Less sensitive & {$[24]$} \\
\hline 7 & $\begin{array}{l}\text { Mobile phase consisting of a } \\
\text { mixture of acetonitrile and } \\
\text { ammonium acetate buffer of } \\
\text { pH-5 }(30: 30: 40, \mathrm{v} / \mathrm{v} / \mathrm{v})\end{array}$ & UPLC & $0.2-3 \mu \mathrm{g} / \mathrm{mL}$ & $\begin{array}{l}\text { Highly sensitive and } \\
\text { selective }\end{array}$ & Developed method \\
\hline
\end{tabular}

TABLE 2: System suitability data.

\begin{tabular}{lccc}
\hline Property & $\begin{array}{c}\text { Mean } \pm \text { SD, } \\
(n=6)\end{array}$ & RSD (\%) & Required limits \\
\hline Retention time $(\mathrm{Rt})$ & $2.22 \pm 0.01$ & 0.32 & $\mathrm{RSD} \leq 2 \%$ \\
Tailing factor $(T)$ & $1.12 \pm 0.008$ & 0.95 & $T \leq 2$ \\
Theoretical plates $(N)$, & $2979 \pm 55$ & 1.11 & $N>2000$ \\
Capacity factor $(k)$ & $1.198 \pm 0.005$ & 0.44 & - \\
\hline
\end{tabular}

\subsection{Method Validation}

2.7.1. Linearity and Range. To establish linearity, eight point calibration standards of the following concentrations $0.2,0.5$, $1.0,1.5,2.0$, and $3.0 \mu \mathrm{g} / \mathrm{mL}$ were prepared; three independent determinations were performed at each concentration. Aliquots of $2.0 \mu \mathrm{L}$ were injected in triplicate (six injections) and eluted with the mobile phase under the reported chromatographic conditions. Calibration curve was constructed by plotting the concentration of IMH versus corresponding mean peak area. The correlation coefficient $\left(r^{2}\right)$, slope $(b)$, and intercept $(a)$ of the calibration curve were calculated.

2.7.2. Accuracy. Accuracy was evaluated as percentage relative error (\% RE) between the measured mean concentrations and taken concentrations. Pure IMH solutions at three different concentrations were analyzed in six replicates during the same day (intraday) and on three different days (interday).
TABLE 3: Linearity and regression parameters with precision data.

\begin{tabular}{lc}
\hline Parameter & Value \\
\hline Linear range in $\mu \mathrm{g} / \mathrm{mL}$ & $0.2-3.0$ \\
Limits of quantification (LOQ) $\mathrm{ng} / \mathrm{mL}$ & 0.7672 \\
Limits of detection (LOD) $\mathrm{ng} / \mathrm{mL}$ & 0.2532 \\
Regression equation & \\
$\quad$ Slope $(b)$ & -2259.6815 \\
$\quad$ Intercept $(a)$ & 152670.3379 \\
Correlation coefficient $\left(r^{2}\right)$ & 0.9997 \\
Standard deviation of $b,\left(S_{b}\right)$ & 1980.26 \\
Standard deviation of $a,\left(S_{a}\right)$ & 5214.63 \\
\hline
\end{tabular}

Further the accuracy of the proposed method is confirmed by performing recovery experiments by standard addition technique. The accuracy of the method for IMH was evaluated in triplicate $(n=3)$ by adding three concentrations of $0.5,1.0$, and $1.5 \mu \mathrm{g} / \mathrm{mL}(50 \%, 100 \%$, and $150 \%)$ of the pure drug to the preanalyzed formulations and the recovery was calculated.

2.7.3. Precision. The precision of the method was determined using six independent test solutions. Inter- and intraday variation and analyst variation were studied to determine the intermediate precision of the proposed method. Six injections of three different concentrations $(0.5,1.0$, and 


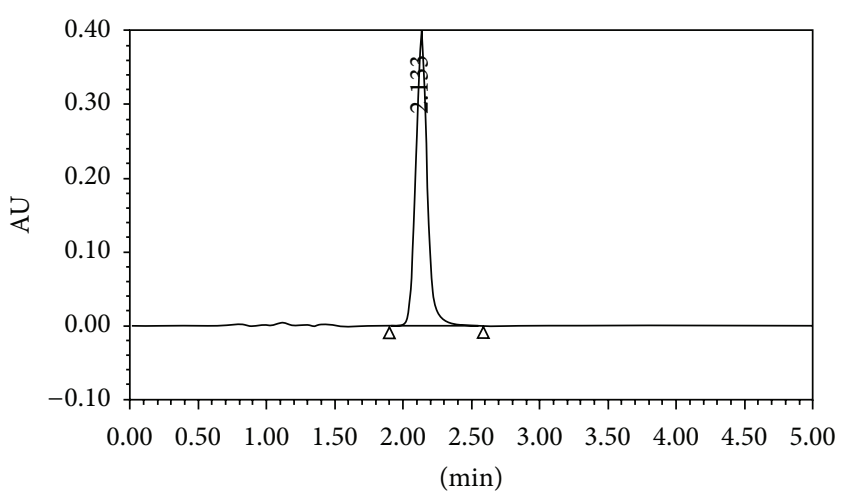

(a)

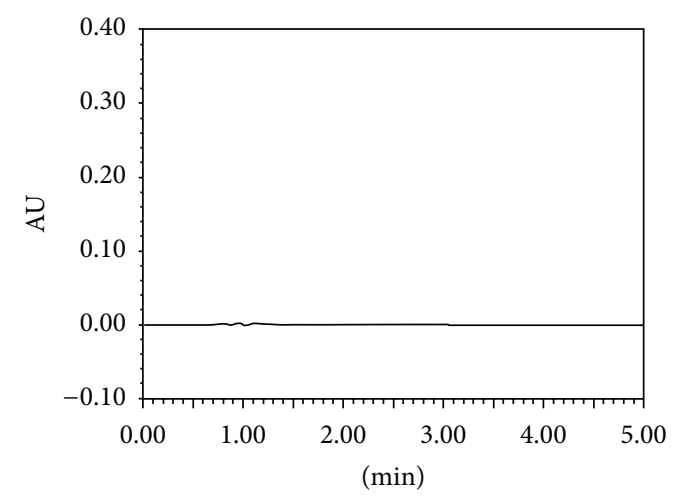

(b)

FIGURE 2: Typical chromatogram of (a) IMH (10 $\mu \mathrm{g} / \mathrm{mL})$; (b) blank.

TABLE 4: Results of accuracy study $(n=5)$ by the proposed method.

\begin{tabular}{|c|c|c|c|c|}
\hline \multirow{2}{*}{$\begin{array}{l}\text { Concentration of IMH } \\
\text { injected in } \mu \mathrm{g} / \mathrm{mL}\end{array}$} & \multicolumn{2}{|c|}{ Intraday } & \multicolumn{2}{|c|}{ Interday } \\
\hline & $\begin{array}{l}\text { Concentration of IMH } \\
\text { found in } \mu \mathrm{g} / \mathrm{mL}\end{array}$ & $\mathrm{RE} \%$ & $\begin{array}{l}\text { Concentration of IMH } \\
\text { found in } \mu \mathrm{g} / \mathrm{mL}\end{array}$ & $\mathrm{RE} \%$ \\
\hline 0.5 & 0.495 & 1.07 & 0.502 & -0.47 \\
\hline 1 & 0.972 & 2.82 & 1.031 & -3.07 \\
\hline 2 & 1.953 & 2.36 & 1.984 & 0.81 \\
\hline
\end{tabular}

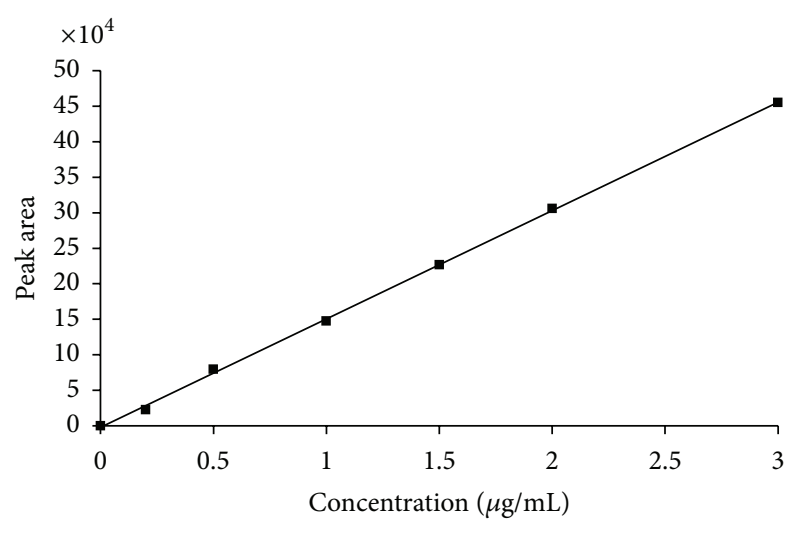

FIGURE 3

$2.0 \mu \mathrm{g} / \mathrm{mL}$ ) were given on the same day (intraday) and the values of relative standard deviation (RSD) were calculated to determine intraday precision. The same protocol was followed for three different days to study interday variation $(n=3)$.

2.7.4. Sensitivity. Sensitivity of the method was proved by establishing the limits of detection (LOD) and quantitation (LOQ) for IMH in pure and in dosage forms. The LOD and LOQ for IMH were determined at a signal-to-noise ratio of $3: 1$ and $10: 1$, respectively, by injecting a series of dilute solutions with known concentrations. Precision study was also carried out at the LOQ level by injecting six $(n=6)$ individual preparations and calculating the \% RSD for the obtained peak area for IMH.
2.7.5. Robustness and Ruggedness. The robustness of an analytical procedure is a measure of its capacity to remain unaffected by small, but deliberate variations in method parameters and provides an indication of its reliability during normal usage. The factors chosen for this study which were critical sources of variability in the operating procedures such as mobile phase $\mathrm{pH}( \pm 0.5)$, temperature of the column $\left( \pm 5^{\circ} \mathrm{C}\right)$, flow rate $( \pm 0.05 \mathrm{~mL} / \mathrm{min})$, mobile phase composition $(70: 30,75: 25$, and $85: 15$; buffer $:$ solvent, v/v), and detection wavelength $(220 \pm 2 \mathrm{~nm})$ were the varied parameters. To determine the ruggedness of the method, three different columns of the same dimensions were used for the analyses. The study was performed in the same day and three different days by three different analysts for three different concentrations of IMH (triplicate injections).

2.7.6. Stability of Solution and Mobile Phase. Stability of IMH working solution was established by storage of sample solution at ambient temperature for $24 \mathrm{~h}$. Sample solution was reanalyzed after $24 \mathrm{~h}$ and assay was determined and compared against fresh sample. The mobile phase study was demonstrated by injecting the freshly prepared sample solution at different time intervals ( 0,12 , and 24 hours) and RSD values of the peak areas were calculated.

\section{Results and Discussion}

3.1. Method Development and Optimization. The UPLC procedure was optimized with a view to developing a method for stability-indicating assay. In order to get good chromatographic results and better retention times, the parameters 


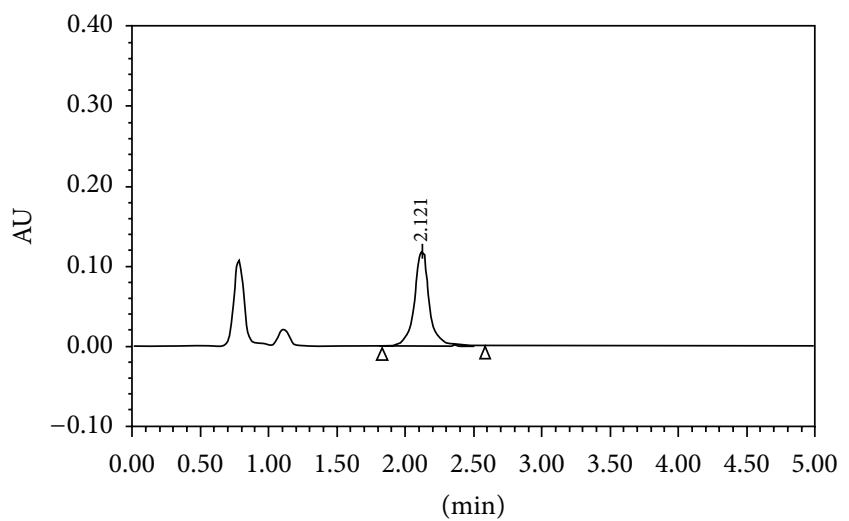

(a)

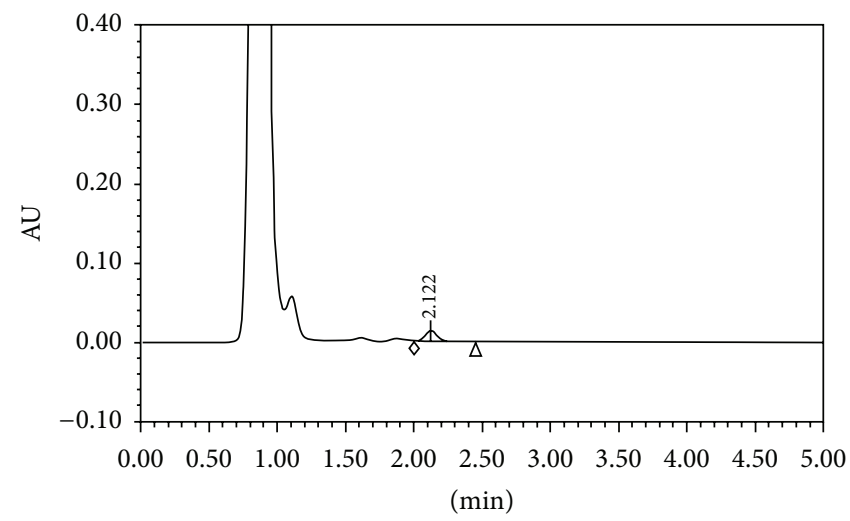

(c)

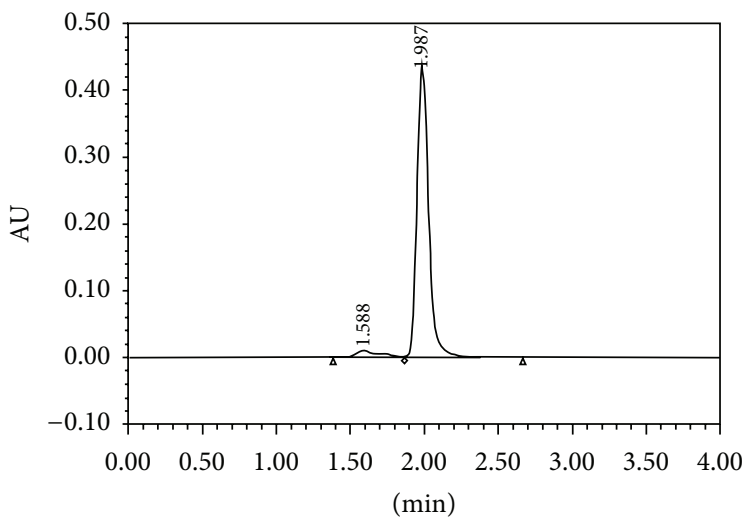

(b)

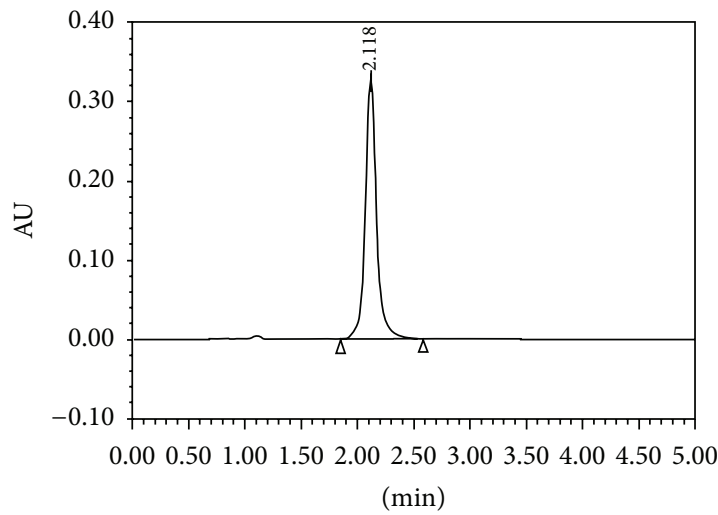

(d)

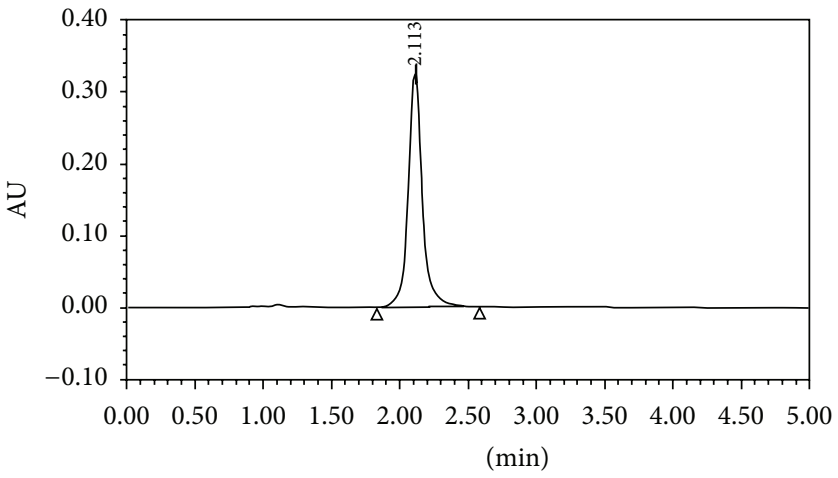

(e)

FIgURE 4: (a) Acid degradation, (b) base degradation, (c) oxidative degradation, (d) thermal degradation, and (e) photodegradation.

TABLE 5: Results of the precision study $(n=5)$ by the proposed method.

\begin{tabular}{|c|c|c|c|c|}
\hline \multirow{2}{*}{$\begin{array}{l}\text { Concentration of IMH } \\
\text { injected in } \mu \mathrm{g} / \mathrm{mL}\end{array}$} & \multicolumn{2}{|c|}{ Intraday precision } & \multicolumn{2}{|c|}{ Interday precision } \\
\hline & Mean area \pm SD & $\% \mathrm{RSD}^{\mathrm{a}}$ & Mean area \pm SD & $\% \mathrm{RSD}^{\mathrm{a}}$ \\
\hline 0.5 & $79292 \pm 30.04$ & 0.0379 & $79289 \pm 37.58$ & 0.0474 \\
\hline 1 & $147141 \pm 50.033$ & 0.0342 & $147151 \pm 55.08$ & 0.0374 \\
\hline 2 & $305505 \pm 95.04$ & 0.0311 & $226543 \pm 60.83$ & 0.0269 \\
\hline
\end{tabular}

${ }^{a}$ Relative standard deviation based on peak area. 


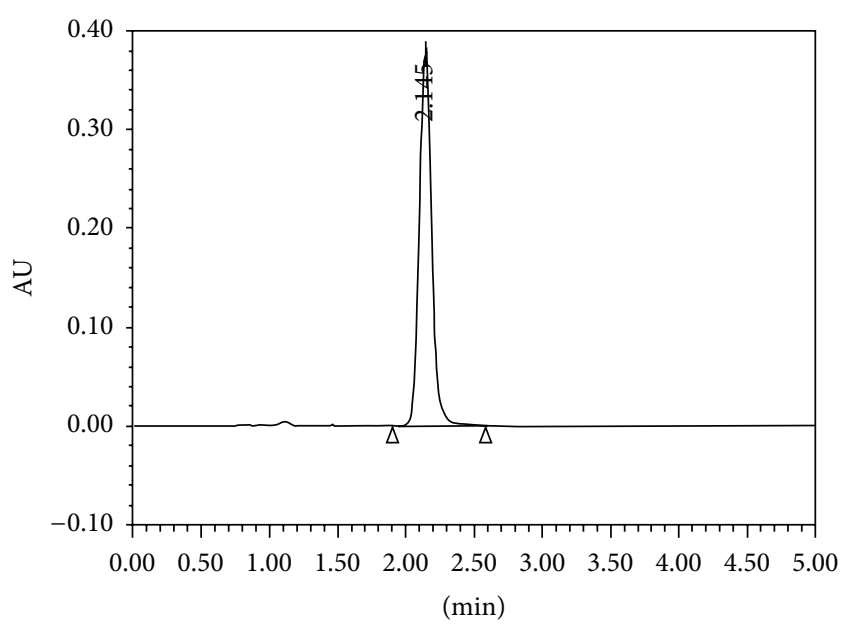

(a)

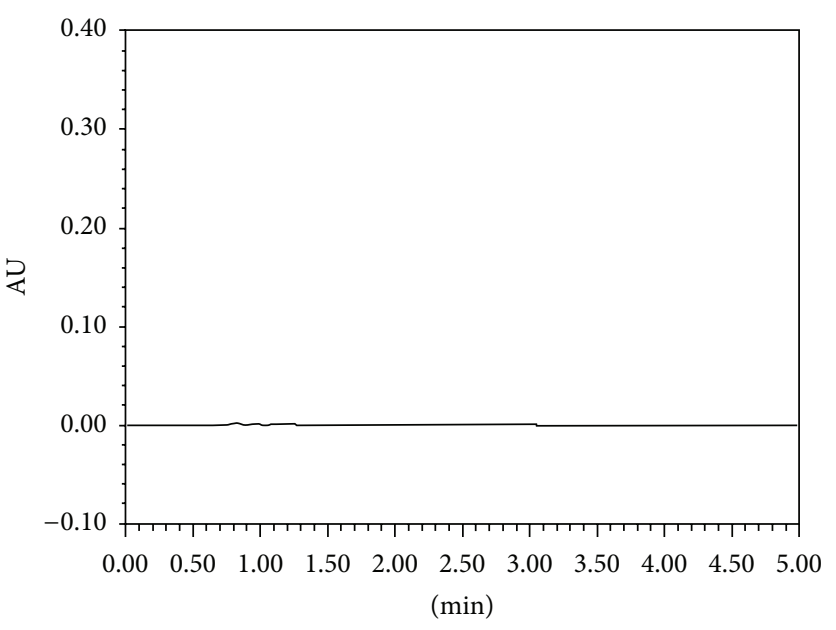

(b)

Figure 5: (a) Chromatogram of tablet extract; (b) chromatogram of placebo blank.

TABLE 6: Method robustness.

\begin{tabular}{lcccccccccc}
\hline Condition & Modification & $\begin{array}{c}\text { Mean peak } \\
\text { area } \pm \text { SD }\end{array}$ & \% RSD & Mean Rt \pm SD & $\begin{array}{c}\text { \% RSD } \\
\text { plates } \pm \text { SD }^{*}\end{array}$ & $\begin{array}{c}\text { Mean theoretical RSD } \\
\text { plactor } \pm \text { SD }\end{array}$ & $\begin{array}{c}\text { Mean tailing } \\
\text { fasD }\end{array}$ \\
\hline Temperature $\left({ }^{\circ} \mathrm{C}\right)$ & 20 & $147204 \pm 105.0$ & 0.88 & $2.01 \pm 0.01$ & 0.55 & $2976 \pm 43$ & 1.43 & $1.101 \pm 0.004$ & 0.35 \\
& 25 & $147271 \pm 157.2$ & 1.09 & $2.12 \pm 0.02$ & 0.72 & $3067 \pm 59$ & 1.94 & $1.117 \pm 0.003$ & 0.23 \\
& 30 & $147144 \pm 156.3$ & 1.52 & $1.99 \pm 0.01$ & 0.33 & $3119 \pm 64$ & 2.07 & $1.108 \pm 0.003$ & 0.24 \\
\hline \multirow{2}{*}{ Mobile phase } & $70: 30$ & $147371 \pm 147.3$ & 0.84 & $2.01 \pm 0.01$ & 0.57 & $2979 \pm 28$ & 0.96 & $1.020 \pm 0.003$ & 0.29 \\
composition & $75: 25$ & $147304 \pm 260.8$ & 1.32 & $2.12 \pm 0.01$ & 0.47 & $3040 \pm 52$ & 1.68 & $1.110 \pm 0.001$ & 0.32 \\
& $85: 15$ & $147511 \pm 295.1$ & 1.68 & $2.00 \pm 0.01$ & 0.36 & $3119 \pm 65$ & 2.07 & $1.050 \pm 0.007$ & 0.67 \\
\hline \multirow{3}{*}{ Flow rate } & 0.25 & $147307 \pm 110.15$ & 0.63 & $1.99 \pm 0.004$ & 0.23 & $3079 \pm 12$ & 0.39 & $1.110 \pm 0.004$ & 0.36 \\
& 0.30 & $147171 \pm 163.7$ & 0.42 & $2.11 \pm 0.005$ & 0.24 & $3104 \pm 8$ & 0.16 & $1.110 \pm 0.004$ & 0.34 \\
& 0.35 & $147211 \pm 110.00$ & 0.76 & $2.11 \pm 0.0606$ & 0.26 & $3129 \pm 12$ & 0.41 & $1.108 \pm 0.003$ & 0.28 \\
\hline \multirow{2}{*}{ Wavelength } & $218 \mathrm{~nm}$ & $147341 \pm 163.71$ & 0.34 & $2.12 \pm 0.003$ & 0.14 & $3019 \pm 24$ & 0.81 & $1.124 \pm 0.005$ & 0.45 \\
& $220 \mathrm{~nm}$ & $147218 \pm 215.48$ & 0.38 & $2.11 \pm 0.003$ & 0.12 & $3169 \pm 26$ & 0.84 & $1.117 \pm 0.003$ & 0.23 \\
& $222 \mathrm{~nm}$ & $147254 \pm 58.59$ & 0.48 & $2.12 \pm 0.004$ & 0.17 & $3153 \pm 30$ & 0.95 & $1.106 \pm 0.005$ & 0.46 \\
\hline
\end{tabular}

${ }^{*}$ Mean value of three determinations.

such as mobile phase composition, column, column temperature, wavelength of detection, $\mathrm{pH}$ of mobile phase, and diluents were optimized. The chromatographic conditions, especially the composition of mobile phase, could affect the separation. Therefore, the optimization of mobile phase components was critical. Of the several solvents and solvent mixtures investigated acetonitrile, and ammonium acetate buffer of $\mathrm{pH}-5(80: 20, \mathrm{v} / \mathrm{v})$ was found to produce fine sharp, well-defined peaks with very good separation and low retention time $(2.0 \mathrm{~min})$. Alternative combinations of gradient and isocratic methods were also performed to obtain a suitable peak. Finally, the isocratic method was found to be suitable for the assay.

The chromatographic separation was achieved on Acquity $\mathrm{BEH} \mathrm{C} 18,100 \mathrm{~mm} \times 2.1 \mathrm{~mm}, 1.7 \mu \mathrm{m}$ column maintained at ambient temperature. The feasibility of various mixture(s) of solvents such as acetonitrile and ammonium acetate buffer with $\mathrm{pH}$ of 5 , along with flow rates $0.3 \mathrm{~mL} / \mathrm{min}$, was tested for complete chromatographic resolution of the IMH. Using the mentioned chromatographic conditions, well-resolved sharp peak was obtained at retention time of 2 min for IMH.

Attempts were made with gradient elution with solvent (ammonium acetate buffer, acetonitrile, and methanol) using phenyl $50 \mathrm{~mm} \times 2.1 \mathrm{~mm}, 2 \mu \mathrm{m}$, column. However, in the above column and intended experimental conditions, columns ended with inconsistent retention time and peak fronting. The peak eluted before 1.5 minutes with a tailing factor of 2, when Acquity BEH C18, $100 \mathrm{~mm} \times 2.1 \mathrm{~mm}$, $1.7 \mu \mathrm{m}$ column was used for the elution. However, verified other buffer solutions like (citric acid/sodium citrate; sodium acetate/acetic acid; disodium hydrogen phthalate/sodium dihydrogen orthophosphate); column oven temperature is also studied at room temperature $25^{\circ} \mathrm{C}$; in view of possible interference study, attempts were also made by adjusting the mobile phase flow rate. However, no significant impact is 
TABLE 7: Method ruggedness.

\begin{tabular}{|c|c|c|c|c|c|c|c|c|}
\hline Variable & $\begin{array}{l}\text { Mean peak } \\
\text { area } \pm \mathrm{SD}^{*}\end{array}$ & $\% \mathrm{RSD}$ & Mean Rt $\pm S D$ & \% RSD & $\begin{array}{l}\text { Mean theoretical } \\
\text { plates } \pm \mathrm{SD}^{*}\end{array}$ & $\%$ RSD & $\begin{array}{l}\text { Mean tailing } \\
\text { factor } \pm \text { SD }\end{array}$ & $\%$ RSD \\
\hline Analyte $(n=3)$ & $147474 \pm 151.74$ & 0.103 & $2.128 \pm 0.006$ & 0.28 & $2938 \pm 73$ & 2.48 & $1.13 \pm 0.004$ & 0.311 \\
\hline Column $(n=3)$ & $147547 \pm 195.53$ & 0.133 & $2.129 \pm 0.006$ & 0.30 & $2875 \pm 81$ & 2.81 & $1.15 \pm 0.008$ & 0.73 \\
\hline
\end{tabular}

${ }^{*}$ Mean value of three determinations.

TABLE 8: Summary of forced degradation results.

\begin{tabular}{lcccc}
\hline Degradation condition & Time & Drug decomposed (\%) ${ }^{*}$ & $\begin{array}{c}\text { \% of drug remaining } \\
\text { after degradation }\end{array}$ & Remarks \\
\hline $\mathrm{HCl} 1 \mathrm{M}$ at $80^{\circ} \mathrm{C}$ & $6 \mathrm{~h}$ & 19.98 & 80.02 & Degradation \\
$\mathrm{NaOH} 1 \mathrm{M}$ at $80^{\circ} \mathrm{C}$ & $6 \mathrm{~h}$ & 10.55 & 89.45 & Degradation \\
Water hydrolysis $\left(80^{\circ} \mathrm{C}\right)$ & $6 \mathrm{~h}$ & 0.98 & 99.02 & No degradation \\
Oxidation by $\mathrm{H}_{2} \mathrm{O}_{2}(5 \%), 80^{\circ} \mathrm{C}$ & $6 \mathrm{~h}$ & 13.13 & 86.9 & Degradation \\
Thermal solid, $80^{\circ} \mathrm{C}$ & $24 \mathrm{~h}$ & 1.09 & 98.91 & Negligible degradation \\
$\mathrm{UV}$ at $220 \mathrm{~nm}$ & $\begin{array}{c}\text { Kept in a } \\
\text { photostability }\end{array}$ & 1.42 & 98.58 & Negligible degradation \\
\end{tabular}

${ }^{*}$ Mean value of three replicates.

observed on the critical chromatographic parameters. Use of ion pair reagents also did not yield the expected peak. At 80:20 ratio of the mobile phase in the linear gradient program, a perfect peak was eluted. Thus, the mobile phase ratio was fixed at $80: 20$ (acetonitrile: buffer) in an isocratic mobile phase flow rate. The typical chromatograms obtained for blank and pure IMHs from final UPLC conditions are depicted in Figure 2.

3.2. Method Validation. The proposed method was validated for system suitability, linearity, LOD, LOQ, inter- and intraday accuracies and precisions, robustness, ruggedness, selectivity, and recovery for the assay of IMH by UPLC according to the ICH guidelines [26].

3.2.1. System Suitability. System-suitability tests are an integral part of method development and are used to ensure adequate performance of the chromatographic system. Choice of retention time $(\mathrm{Rt})$, tailing factor $(T)$, theoretical plates $(N)$, and capacity factor $(k)$ was the major task while developing the method and was evaluated for six replicate injections of the drug at a concentration of $1 \mu \mathrm{g} / \mathrm{mL}$. The results presented in Table 2 are within the acceptable limits.

3.2.2. Linearity and Limit of Detection and Quantitation. For $\mathrm{IMH}$, a linear calibration curve was obtained ranging from 0.2 to $3.0 \mu \mathrm{g} / \mathrm{mL}$. The slope, intercept, correlation coefficient $\left(r^{2}\right)$, standard deviation of slope, and intercept were calculated from linear regression analysis. The correlation coefficient is greater than 0.999. LOD, LOQ, and characteristic parameters for regression equation observed during the course of validation are given in Table 3 . The calibration curve for the proposed method is given in Figure 3.
3.2.3. Accuracy. The accuracy of the assay method was evaluated in triplicate at three concentration levels in bulk drug sample. The peak-area-based and retention-time-based relative error values were $<1 \%$. The result obtained for the evaluation of accuracy of the method is shown in Table 4.

3.2.4. Precision. The precision of the assay method was evaluated by carrying out five independent assays. The \% RSD of assay of IMH determination was within the acceptable limit of $1 \%$. Intraday precision of the proposed method was evaluated by assaying freshly prepared solutions in triplicates at three different concentrations. Interday precision was evaluated by using freshly prepared solution in triplicates on three different days. These results are summarized in Table 5.

3.2.5. Robustness and Ruggedness. The robustness of an analytical procedure is a measure of its capacity to remain unaffected by small, but deliberate variations of the analytical conditions. In all the deliberately varied chromatographic conditions (flow rate, column temperature, mobile phase composition, and $\mathrm{pH}$ variation), all of the analyte peaks were adequately resolved, and the order elution remained unchanged which indicates that the method is robust. In method ruggedness, different columns (same lot), at different days by different analysts, were performed. The results obtained are shown in Tables 6 and 7.

3.2.6. Solution Stability and Mobile Phase Stability. No significant change in the chromatographic parameters was observed during the solution stability study. At the specified time interval, the RSD (\%) values for the IMH assay during solution stability and mobile phase stability experiments were within $1 \%$. Stability of sample solution was established by storage of sample solution at ambient temperature $\left(25^{\circ} \mathrm{C}\right)$ for 
TABLE 9: Results of determination of IMH in tablet and statistical comparison with the reference method.

\begin{tabular}{lccccc}
\hline Formulation brand name & \multicolumn{2}{c}{ Nominal amount, mg/tab } & \% IMH found ${ }^{*} \pm$ SD \\
& & Reference method & Proposed method & $t$-value & $F$-value \\
\hline Imipramine $^{\mathrm{a}}$ & $25 \mathrm{mg}$ & $99.38 \pm 0.30$ & $99.95 \pm 0.15$ & 2.007 & 4.064 \\
Depranil $^{\mathrm{b}}$ & $25 \mathrm{mg}$ & $99.55 \pm 0.22$ & $100.04 \pm 0.13$ & 2.174 & 2.723 \\
\hline
\end{tabular}

Marketed by ${ }^{\mathrm{a}}$ Sun and ${ }^{\mathrm{b}} \mathrm{La}$ Pharma.

${ }^{*}$ Mean value of five determinations.

Tabulated $t$-value at $95 \%$ confidence level is 2.78 ; tabulated $F$-value at $95 \%$ confidence level is 6.39 .

TABLE 10: Results of recovery study by standard addition method.

\begin{tabular}{lcccc}
\hline Tablet studied & $\mathrm{IMH}$ in tablet, $\mu \mathrm{g} / \mathrm{mL}$ & Pure IMH added, $\mu \mathrm{g} / \mathrm{mL}$ & Total found, $\mu \mathrm{g} / \mathrm{mL}$ & Pure IMH recovered* $(\% \mathrm{IMH} \pm \mathrm{SD})$ \\
\hline \multirow{3}{*}{ Impramine } & 0.5 & 0.5 & 0.998 & $99.84 \pm 0.09$ \\
& 0.5 & 1.0 & 1.502 & $100.22 \pm 0.11$ \\
\hline \multirow{3}{*}{ Depranil } & 0.5 & 1.5 & 1.996 & $99.79 \pm 0.25$ \\
& 0.5 & 0.5 & 1.004 & $100.89 \pm 0.04$ \\
& 0.5 & 1.0 & 1.495 & $99.54 \pm 0.12$ \\
\end{tabular}

${ }^{*}$ Mean value of five determinations.

$24 \mathrm{~h}$. Sample solution was reanalyzed after 12 and $24 \mathrm{~h}$ time intervals. The results from the solution stability and mobile phase stability experiments confirmed that the standard solutions of drug and solutions in the mobile phase were stable at ambient temperature up to $24 \mathrm{~h}$ during the assay. The results in Table 6 show no appreciable change in its system suitability criteria.

3.2.7. Degradation Results. Stress testing provides evidence on how the quality of a drug may be affected under the influence of different stress conditions. All forced degradation samples were analyzed at $100 \mu \mathrm{g} / \mathrm{mL}$ concentration level. The method was capable of separating degradation products in the presence of IMH; well-separated analyte and degradation peaks were obtained after all degradation experiments. Acidic and basic stress led to 19.98 and $10.55 \%$ degradation, respectively. About $13.13 \%$ degradation was observed under oxidative stress conditions $\left(5 \% \mathrm{H}_{2} \mathrm{O}_{2}\right)$, while degradation was not observed in IMH samples under stress conditions like neutral and photolytic stress conditions. IMH was also observed to be thermally stable, and no decomposition was seen on exposure of solid drug powder to dry heat at $80^{\circ} \mathrm{C}$ or on expose to moist heat conditions (Figure 4 ). The drug was found to be sensitive to acid, base, and oxidative hydrolysis. IMH was found to be more stable under neutral, photolytic (photostability chamber for 10 days), and thermal $\left(80^{\circ} \mathrm{C}\right.$ for $\left.24 \mathrm{~h}\right)$ solid state conditions. This forced degradation studies show that the method enables selective and specific differentiation of the degradation peaks from the analyte peak (Figure 4). Results from forced degradation studies are presented in Table 8.

3.2.8. Selectivity of the Method. Selectivity is the ability of the method to assess obviously the analyte in the presence of components, which may be expected to be present. Typically, these might include degradants, matrix, and so forth.
Method selectivity was evaluated by injecting the mobile phase, placebo blank, pure drug solution, and tablet extract. Figures 5(a) and 5(b) demonstrate the selectivity experiments with the chromatograms of tablet extracts. No peaks were observed for mobile phase and placebo blank, and no extra peaks were observed for tablet extracts.

3.2.9. Application of the Method to Dosage Forms. The present method was applied for the estimation of drugs and common excipients in the commercially available various dosage forms. A $1 \mu \mathrm{g} / \mathrm{mL}$ solution of tablets was prepared as per "preparation of sample solution" and injected in triplicate to the UPLC system. The validity of the proposed method was ascertained by the statistical comparison of the results obtained by the reported HPLC method [4] with the proposed method by applying Student's $t$-test for accuracy and $F$-test for precision in some commercial formulations. The results obtained are as shown in Table 9, and the $t$ - and Fvalues at $95 \%$ confidence level did not exceed the tabulated values and this further confirms that there is no significant difference between the reference and proposed methods with respect to accuracy and precision.

3.2.10. Recovery Study. The accuracy of the proposed method was further ascertained by performing recovery studies via standard addition technique. The sample is analysed for the analyte of interest by adding a specified amount of pure IMH to the sample, thus increasing its concentration. The solutions were prepared by spiking preanalyzed tablet with pure drug at three different levels and injected to chromatographic column. The recovery of the known amount of added analyte was computed. The percentage recovery of IMH from pharmaceutical dosage forms ranged from 99.33 to $101.06 \%$. The results presented in Table 10 reveal good accuracy of the proposed method. 


\section{Conclusions}

The rapid isocratic RP-UPLC method developed for quantitative analysis of IMH in pharmaceutical dosage forms is precise, accurate, linear, robust, and specific. This newly developed UPLC method for IMH assay determination was found to be capable of giving faster retention times, maintaining good resolution; the method was completely showing satisfactory data for all the parameters tested. This method gives excellent performance in terms of sensitivity, speed, and especially concerning in the decrease of time and solvent consumption when compared to most of the reported chromatography/spectrophotometric methods (Table 1). Stress testing is an important aspect of the drug development process. The results of stress testing were undertaken according to International Conference on Harmonization guidelines reveal that it is a stability indicating method suitable for rapid analysis of imipramine hydrochloride in bulk drug and in dosage forms. Hence, the method developed is recommended for the routine studies in the industries.

\section{Acknowledgments}

The authors are grateful to Cipla Ltd. India, for the generous supply of pure drug sample. One of the authors, H. N. Deepakumari, is thankful to the University of Mysore, Mysore, India, for providing the necessary facilities.

\section{References}

[1] J. G. Hardman, L. E. Limbird, P. B. Molonoff, R. W. R. Ruddon, and A. G. Gilman, Goodman and Gilman's the Pharmacological Basis of therapeutics, McGraw-Hill, New York, NY, USA, 1996.

[2] European Pharmacopoeia, vol. 5, p. 1792, 2005.

[3] S. K. Patel and N. J. Patel, "Simultaneous determination of imipramine hydrochloride and chlordiazepoxide in pharmaceutical preparations by spectrophotometric, rp-hplc, and hptlc methods," Journal of AOAC International, vol. 93, no. 3, pp. 904910, 2010.

[4] T. Choudhury, A. Ghosh, J. Deb, and A. Bagchi, "Reverse phase high performance liquid chromatographic method and method validation of imipramine by using single mobile phase," International Journal of Pharmaceutical Science and Technology, vol. 4 , p. 54, 2010.

[5] T. B. Zeugin, K. Brosen, and U. A. Meyer, "Determination of imipramine and seven of its metabolites in human liver microsomes by a high-performance liquid chromatographic method," Analytical Biochemistry, vol. 189, no. 1, pp. 99-102, 1990.

[6] F. Pommier, A. Sioufi, and J. Godbillon, "Simultaneous determination of imipramine and its metabolite desipramine in human plasma by capillary gas chromatography with mass-selective detection," Journal of Chromatography B, vol. 703, no. 1-2, pp. 147-155, 1997.

[7] R. F. Suckow and T. B. Cooper, "Simultaneous determination of imipramine, desipramine, and their 2-hydroxy metabolites in plasma by ion-pair reversed-phase high-performance liquid chromatography with amperometric detection," Journal of Pharmaceutical Sciences, vol. 70, no. 3, pp. 257-261, 1981.
[8] E. Koyama, Y. Kikuchi, H. Echizen, K. Chiba, and T. Ishizaki, "Simultaneous high-performance liquid chromatographyelectrochemical detection determination of imipramine, desipramine, their 2-hydroxylated metabolites, and imipramine $\mathrm{N}$-oxide in human plasma and urine: preliminary application to oxidation pharmacogenetics," Therapeutic Drug Monitoring, vol. 15, no. 3, pp. 224-235, 1993.

[9] H. A. Heck, N. W. Flynn, and S. E. Buttrill Jr., "Determination of imipramine in plasma by high pressure liquid chromatography and field ionization mass spectrometry: increased sensitivity in comparison with gas chromatography mass spectrometry," Biomedical Mass Spectrometry, vol. 5, no. 3, pp. 250-257, 1978.

[10] N. Sistovaris, E. E. Dagrosa, and A. Keller, "Thin-layer chromatographic determination of imipramine and desipramine in human plasma and urine at single-dose levels," Journal of Chromatography, vol. 277, pp. 273-281, 1983.

[11] T. B. Cooper, D. Allen, and G. M. Simpson, "A sensitive GLC method for the determination of imipramine and desmethylimipramine using a nitrogen detector," Psychopharmacology Communications, vol. 1, no. 4, pp. 445-454, 1975.

[12] D. Alkalay, J. Volk, and S. Carlsen, "A sensitive method for the simultaneous determination in biological fluids of imipramine and desipra mine or clomipramine and $\mathrm{N}$ desmethylclomipramine by gas chromatography mass spectrometry," Biomedical Mass Spectrometry, vol. 6, no. 5, pp. 200204, 1979.

[13] D. A. Breutzmann and L. D. Bowers, "Reversed-phase liquid chromatography and gas chromatography/mass fragmentography compared for determination of tricyclic antidepressant drugs," Clinical Chemistry, vol. 27, no. 11, pp. 1907-1911, 1981.

[14] S. B. Puranik, V. R. Pawar, N. Lalitha, P. N. Sanjay Pai, and G. K. Rao, "Residual solvent analysis in hydrochloride salts of active pharmaceutical ingredients," Pakistan Journal of Pharmaceutical Sciences, vol. 22, no. 4, pp. 410-414, 2009.

[15] D. Bose, A. Martinavarro-Domínguez, M. Gil-Agustí et al., "Therapeutic monitoring of imipramine and desipramine by micellar liquid chromatography with direct injection and electrochemical detection," Biomedical Chromatography, vol. 19, no. 5, pp. 343-349, 2005.

[16] T. G. Díaz, M. I. Acedo-Valenzuela, N. M. Diez, and A. S. Rodríguez, "Simultaneous differential pulse adsorptive stripping determination of imipramine and its metabolite desipramine by the PLS-1 multivariate method," Electroanalysis, vol. 23, no. 2, pp. 449-455, 2011.

[17] C. K. Markopoulou, E. T. Malliou, and J. E. Koundourellis, "Application of two chemometric methods for the determination of imipramine, amitriptyline and perphenazine in content uniformity and drug dissolution studies," Journal of Pharmaceutical and Biomedical Analysis, vol. 37, no. 2, pp. 249-258, 2005.

[18] T. P. Ruiz, C. M. Lozano, A. Sanz, and C. Alonso, "Flow-injection extraction-spectrophotometric determination of imipramine in pharmaceuticals with methyl orange," Talanta, vol. 41, no. 9, pp. 1523-1527, 1994.

[19] J. M. Garcia Fraga, A. I. Jimenez Abizanda, F. Jimenez Moreno, and J. J. Arias Leon, "Simultaneous determination of imipramine and amitryptiline by derivative spectrophotometry," Journal of Pharmaceutical and Biomedical Analysis, vol. 9, no. 2, pp. 109-115, 1991.

[20] B. A. El Zeany, A. A. Moustafa, and N. F. Farid, "Determination of imipramine in presence of iminodibenzyl and in pharmaceutical dosage form," Journal of Pharmaceutical and Biomedical Analysis, vol. 33, no. 4, pp. 775-782, 2003. 
[21] F. A. El-Yazbi, M. A. Korany, and M. Bedair, "A sensitive colorimetric method for the determination of imipramine hydrochloride and desipramine hydrochloride," Journal of Clinical and Hospital Pharmacy, vol. 10, no. 4, pp. 373-377, 1985.

[22] B. Starczewska, "Spectrophotometric studies and application of imipramine-eriochrome cyanine R system for determination of imipramine in pharmaceuticals," Journal of Pharmaceutical and Biomedical Analysis, vol. 23, no. 2-3, pp. 383-386, 2000.

[23] G. N. Reddy, C. Ramesh, T. V. Narayana, K. V. S. P. Rao, and B. G. Rao, "Development of ion-association methods for spectrophotometric assay of imipramine hydrochloride," International Journal of Chemical Sciences, vol. 9, no. 2, pp. 457464, 2011.

[24] H. D. Revanasiddappa and B. Manju, "Spectrophotometric determination of some antidepressant drugs using 3methylbenzothiazolin-2-one hydrazone," European Journal of Pharmaceutical Sciences, vol. 9, no. 2, pp. 221-225, 1999.

[25] ICH Q1A (R2), "Stability Testing of New Drug Substances and Products, 2003," ICH Q2, (R1), Validation of Analytical Procedures: Text and Methodology, 2005.

[26] T. Q. B. ICH, Validation of Analytical Procedures: Methodology (CPMP/ICH/281/95). Step 4. Consensus Guideline, The European Agency for the Evaluation of Medicinal Products, London, UK, 1996. 

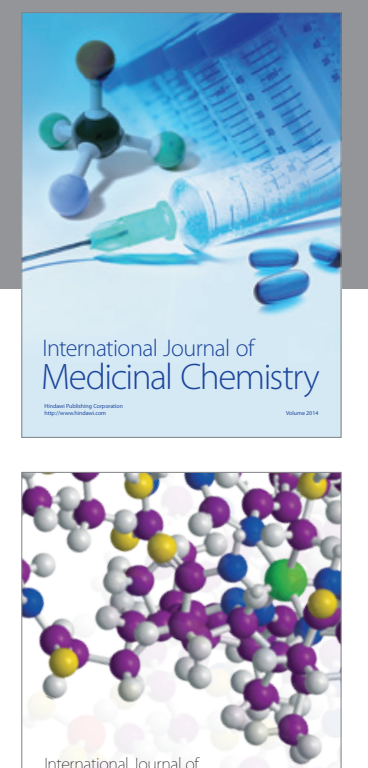

\section{Carbohydrate} Chemistry

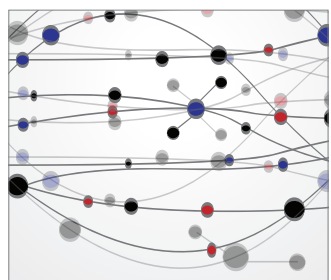

The Scientific World Journal
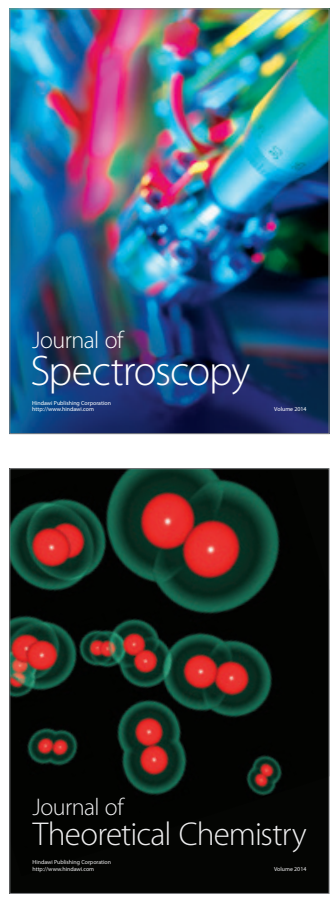
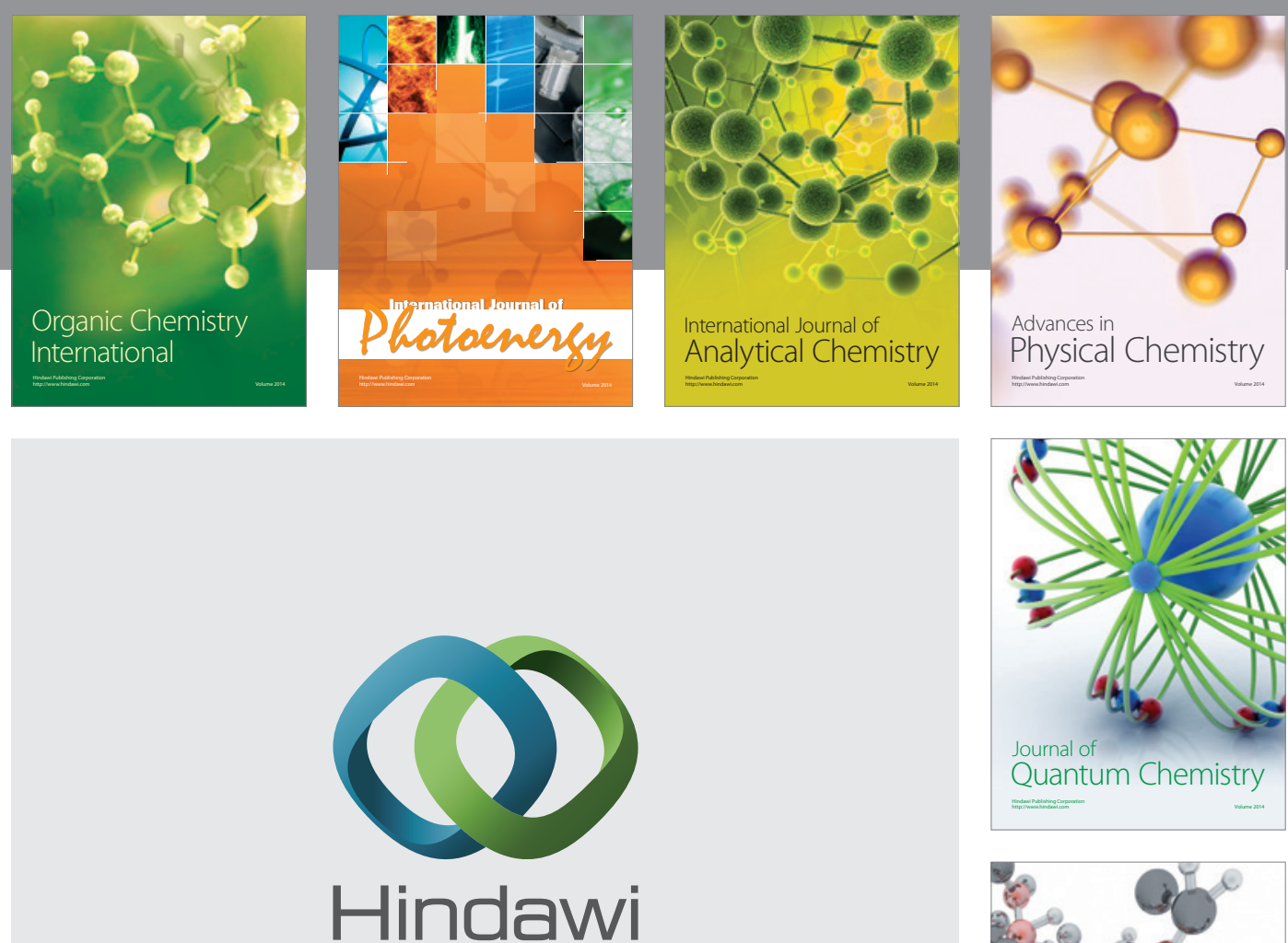

Submit your manuscripts at

http://www.hindawi.com

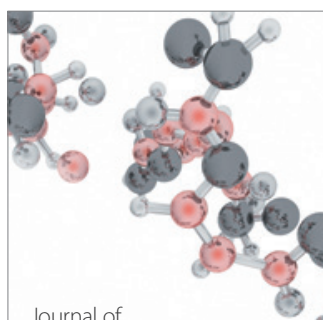

Analytical Methods

in Chemistry

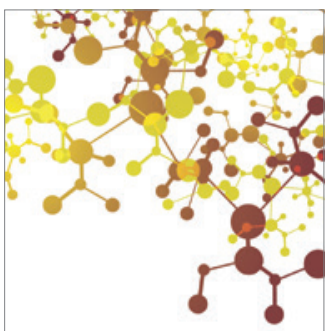

Journal of

Applied Chemistry

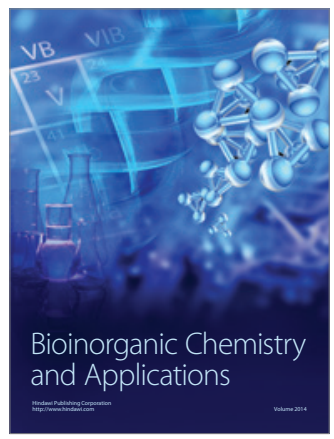

Inorganic Chemistry
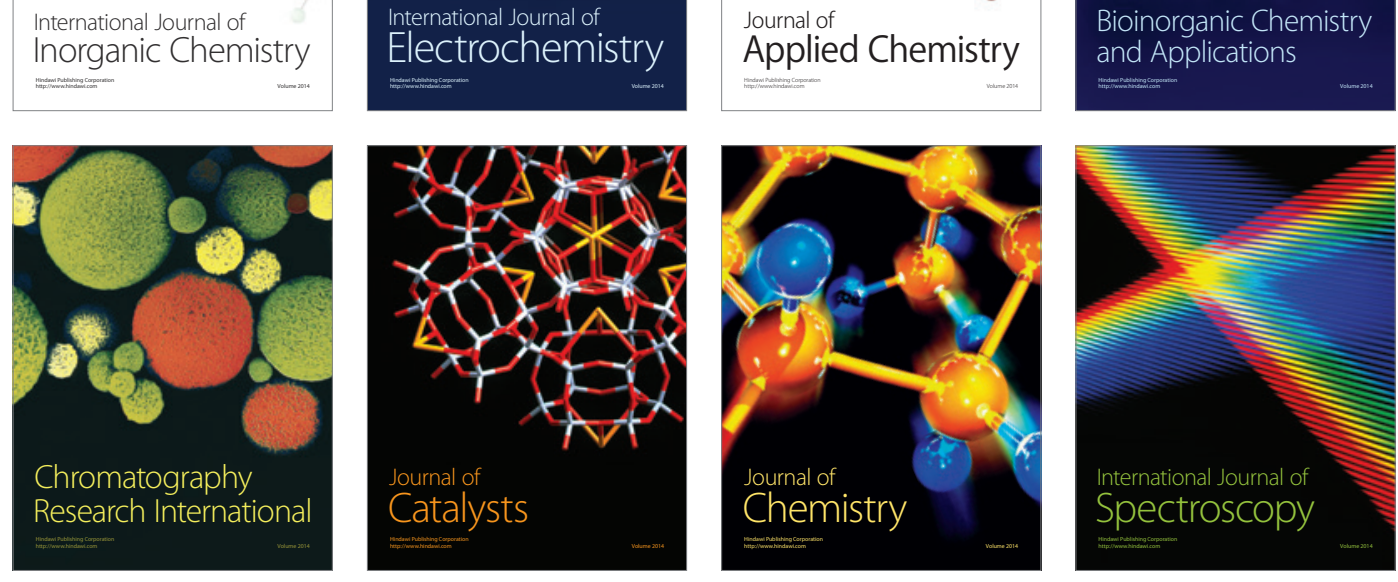